\title{
POLITENESS IN THE SPEECH OF CHARACTER IN \\ "KEY EYE by HELLA S. HAASSE" NOVEL \\ (Content Analysis Methods)
}

\author{
Irfan Firnanda \\ Postgraduate Program, Universitas Negeri Jakarta \\ Jl. Rawa Mangun Muka, Jakarta Timur, DKI Jakarta 13220 \\ Email: if.pkhkemensos@ gmail.com
}

\begin{abstract}
The purpose of this research is to comprehend the language comprehensively in the novel "Key Eye" by HELLA S. HAASSE. This research uses qualitative research with content analysis method. Data were collected through speeches of characters in novels, observations, and recordings. Analysis and interpretation of data shows that politeness in the speech of the character in the novel "Key eye by HELLA S. HAASSE" divided into positive politeness and negative politeness, as well as the maxim according to Geoffrey Leech. These findings can be a recommendation for students to understand the comprehensive politeness by reading the novel "The Key Eye by HELLA S. HAASSE" as an alternative source of learning on politeness. This research is also recommended to the next researcher to use this research as a reference in his research.
\end{abstract}

Key words: Politeness, Maxim, Novel, Content analysis.

\section{INTRODUCTION}

Modesty is a context that can cause social problems in everyday life. One that encompasses the politeness of a person in socializing is language. Language politeness is something that is important for

Pragmatics is one branch of grammar that is closely related to the act of every individual, because every individual interconnected with others by communicate. It is discussed in pragmatic science. saying. Context in a speech act has a very important role. Context in a different

BAHTERA : Jurnal Pendidikan Bahasa dan Sastra, Volume Juli 2018 
situation will affect the meaning of a similar act of speech. Thus, the use of a language may affect the purpose of the words spoken by the speaker.

In pragmatic science, the language studied is not separated and must be in accordance with the context of the language in question. The language and context in pragmatics become an inseparable whole. As in a literary work, the reader feels the pleasure of reading it. But if a literary work has reached its reader, the author or author has no right to his literary work. The right referred to in this case, the right to defend or express the good or cover up the bad work he made from the comments of the reader, be it a positive or negative comment. For example, when someone reads one of the works of literature (novel), there are most of the paragraphs or sentences in the novel that make us dissolved with the diction that the author incised in his work. But the novel will not be separated from good and bad comments, both of which will accompany a novel literary work.

Researchers make the novel as the subject of research because it relates to pragmatic science, about language politeness. In this study, the authors are interested to analyzed graciousness Speaking In the Speech of HELLE S. HAASSE Key Eye novel.

The Key Eye is the story of DEE MIJERS or MILA WYCHINSKA who lived in the end of the Dutch colonial era. Spoken by his loyal friend Herma Warner, Dee's complicated story of life is rooted in a deep sense of hatred for social class differences in that period. The mixed blood that flowed in his body placed Dee in a confusing position between the colonialists and the natives. This mixed blood contradicts each other and boils the anger that makes a young girl have to fight in various struggles against inequality. At the end of his life, Herma dug up the life Dee had gone through. Herma tried to unlock the dusty crate of the past which she always kept tight. The opening of this chest will reveal various secrets, hatred and treachery that can destroy all the memories that have been folded neatly in the memory. From a snippet summary of the story about the novel "Key Eye", the researcher hopes to dig deeper language politeness which according to him with the politeness of language, hence create emotional closeness 
between speaker and speaker opponent, because in this case, language is closely related as communication tool and interaction between individual or group one with the other. Thus language is not only an individual phenomenon, but also as a social phenomenon. As social beings, humans interact with society to nurture and create good relationships with each other, and that interaction is done through communication.

\section{METHOD}

This research focused on language politeness in the novel character of "Key Eye by HELLA S. HAASSE" novel which is seen from the principles of politeness according to Brown and Levinson, as in the table below

Table 2.1

Positive and Negative Patterns Strategy Brown and Levinson

\begin{tabular}{|c|c|}
\hline $\begin{array}{c}\text { Positive Politeness } \\
\text { Strategy }\end{array}$ & $\begin{array}{c}\text { Strategy of } \\
\text { Negative } \\
\text { Politeness }\end{array}$ \\
\hline $\begin{array}{c}\text { 1. Attention to the } \\
\text { likes, desires and }\end{array}$ & $\begin{array}{l}\text { 1. Express } \\
\text { indirectly }\end{array}$ \\
\hline
\end{tabular}

needs of the opponent said

2. Exaggerate the feeling of attraction, approval and sympathy for the opponent

3. intriguing attention to the opponent of speech

4. using a marker that shows the similarity of identity or group

5. Seeks approval with the opponent

6. Avoid conflict with the opponent of speech

7. Shows things that are deemed to have common ground through preamble (small talk) and prejudice (presupposition)

8. Use a joke

9. States understand the will of the opponent said

10. Provide offers and appointments

11. Advance optimism

12. Involving speakers and the speaker's opponent in a particular activity

13. Give and ask advice

14. Offering a mutual action

15. Give sympathy to the opponent said according to

convention

2. Using question form

3. showing a pessimistic attitude

4. minimize coercion

5. Pay homage

6. Using an apology

7. Do not mention speakers and speakers' opponents

8. Uttering speech acts as a general unity

9. Nominate a statement

10. States clearly, that the opponent of speech has given good or not to the speaker 
The Table above according to Brown and Levinson divided into positive politeness with 15 kinds of strategy and negative politeness with 10 kinds of strategy.

And the principle of maxim according to Geoffrey Leech, can be seen in the following table;

Table 3.5 Maxim Criteria According to Leech Theory

\begin{tabular}{|c|c|l|}
\hline No & Maxim & \multicolumn{1}{|c|}{ Criteria } \\
\hline $\mathbf{1}$ & $\begin{array}{c}\text { Maxim } \\
\text { policy }\end{array}$ & $\begin{array}{l}\text { Reduce the losses of } \\
\text { others increase the } \\
\text { benefits of others }\end{array}$ \\
\hline $\mathbf{2}$ & $\begin{array}{c}\text { Maxim } \\
\text { generosity }\end{array}$ & $\begin{array}{l}\text { Reduce self-gain, add } \\
\text { self-sacrifice }\end{array}$ \\
\hline $\mathbf{3}$ & $\begin{array}{c}\text { Maxim } \\
\text { award }\end{array}$ & $\begin{array}{l}\text { Reduce the scolding } \\
\text { to others, add praise } \\
\text { to others }\end{array}$ \\
\hline $\mathbf{4}$ & $\begin{array}{c}\text { Maxim } \\
\text { simplicity }\end{array}$ & $\begin{array}{l}\text { Reduce self-esteem, } \\
\text { add self-censure }\end{array}$ \\
\hline Maxim & $\begin{array}{l}\text { Reduce the } \\
\text { incompatibility } \\
\text { between self and } \\
\text { others, increase the } \\
\text { appropriateness } \\
\text { between oneself with } \\
\text { others }\end{array}$ \\
\hline $\mathbf{6}$ & $\begin{array}{c}\text { Maxim } \\
\text { sympathy }\end{array}$ & $\begin{array}{l}\text { Reduce uncertainty } \\
\text { between yourself and } \\
\text { others, increase the } \\
\text { certainty between } \\
\text { yourself and others }\end{array}$ \\
\hline
\end{tabular}

The maxim principle according to Geoffrey Leech is divided into 6 maxims, the maxim of wisdom, the maxim of generosity, the maxim of appreciation, the maxim of simplicity, the maxim of consensus, and the maxim of sympathy. This study aims to understand more depth of language politeness in the speech of the novel character "The Key Eye of HELLA S. HAASSE" by using a qualitative approach with content analysis research methods. The data used in this study are words of conversation in the novel "Key Eye by HELLA S. HAASSE". The entire novel is read repeatedly until it finds speeches that include positive politeness and negative politeness, then recorded in the form of tables. The technique of examining the validity of data is based on credibility, transferability, dependability, and confirmability. Continuous and indepth observation, tracking the suitability and completeness results of data analysis, consistency throughout the research process, and so on.

\section{RESULTS}

The focus in this study is language politeness in the speech of the novel character of Key Eye by HELLA $S$. HAASSE. Novel Key Eye is a novel

BAHTERA : Jurnal Pendidikan Bahasa dan Sastra, Volume Juli 2018 
written by HELLA S. HAASSE. The author is from the land of windmills, Amsterdam. The Novel Key eye is a novel translated into Bahasa Indonesia by WIDJAJANTI DHARMOWIJONO from an original novel entitled SLEUTELOOG, published in 2002. The novel consists of 204 pages. The theme of the conversation surrounding the story of DEE MIJERS or MILA WYCHINSKA past as the main character, who lived in the end of the Dutch colonial era. Spoken by his loyal friend Herma Warner, Dee's complicated story of life is rooted in a deep sense of hatred for social class differences in that period. The mixed blood that flowed in his body placed Dee in a confusing position between the colonialists and the natives. The story is presented in an elaborate way with a storyline that often tells the past of the main character. The language in this novel also makes the story interesting.

Language courtesy has been found in the speech of the novel Key Eye novel by HELLA S. HAASSE. The findings are described based on the sequence of research questions, namely (1) Positive politeness in the novel by HELLA $S$. HAASSE. (2) Negative politeness in the novel by HELLA S. HAASSE. (3) Maxim courtesy language according to Leech theory in the speech of the novel character of Key Eye by HELLA S. HAASSE.

The analysis of the Locke novel by HELLA S. HAASSE 204 pages and 113 conversations received 177 utterances containing courtesy in HELLA S. HAASSE Key Eye novel with the following details.

Table 4.1

Number of Speech that Contains

Dignity

\begin{tabular}{|c|c|c|c|}
\hline $\begin{array}{l}\mathbf{N} \\
\mathbf{0}\end{array}$ & $\begin{array}{c}\text { Politenes } \\
\text { S }\end{array}$ & $\begin{array}{l}\text { Number } \\
\text { Of } \\
\text { Speeche } \\
\text { s }\end{array}$ & $\begin{array}{c}\text { Percentag } \\
\text { e Of } \\
\text { Speech }\end{array}$ \\
\hline 1 & $\begin{array}{c}\text { Positive } \\
\text { Politenes } \\
\text { S }\end{array}$ & 100 & $56.5 \%$ \\
\hline & strategy 1 & 2 & $1.1 \%$ \\
\hline & strategy 2 & 7 & $4.0 \%$ \\
\hline & $\begin{array}{c}\text { Strategy } \\
3\end{array}$ & 14 & $7.9 \%$ \\
\hline & $\begin{array}{c}\text { Strategy } \\
4\end{array}$ & 8 & $4.5 \%$ \\
\hline & $\begin{array}{c}\text { Strategy } \\
5\end{array}$ & 12 & $6.8 \%$ \\
\hline & $\begin{array}{c}\text { Strategy } \\
6\end{array}$ & 6 & $3.4 \%$ \\
\hline & $\begin{array}{c}\text { Strategy } \\
7\end{array}$ & 4 & $2.3 \%$ \\
\hline & $\begin{array}{c}\text { Strategy } \\
8\end{array}$ & 1 & $0.6 \%$ \\
\hline & $\begin{array}{c}\text { Strategy } \\
9\end{array}$ & 2 & $1.1 \%$ \\
\hline & $\begin{array}{c}\text { Strategy } \\
10\end{array}$ & 3 & $1.7 \%$ \\
\hline
\end{tabular}




\begin{tabular}{|c|c|c|c|}
\hline & $\begin{array}{c}\text { Strategy } \\
11\end{array}$ & 11 & $6.2 \%$ \\
\hline & $\begin{array}{c}\text { Strategy } \\
12\end{array}$ & 1 & $0.6 \%$ \\
\hline & $\begin{array}{c}\text { Strategy } \\
13\end{array}$ & 5 & $2.8 \%$ \\
\hline & Strategy & - & - \\
\hline & Strategy & & \\
\hline & 15 & 6 & $3.4 \%$ \\
\hline & Mixed & 18 & 10 ᄀ \\
\hline & Strategy & 10 & $10.2 \%$ \\
\hline & Negative & & \\
\hline 2 & $\begin{array}{c}\text { Politenes } \\
\text { s }\end{array}$ & 77 & $43.5 \%$ \\
\hline & $\begin{array}{c}\text { Strategy } \\
1\end{array}$ & 2 & $1.1 \%$ \\
\hline & Strategy & 37 & $20.9 \%$ \\
\hline & Strategy & & \\
\hline & 3 & 13 & $7.3 \%$ \\
\hline & Strategy & 2 & $1.1 \%$ \\
\hline & Strategy & & \\
\hline & 5 & 3 & $1.7 \%$ \\
\hline & Strategy & & - \\
\hline & 6 & & \\
\hline & $\begin{array}{c}\text { Strategy } \\
7\end{array}$ & 6 & $3.4 \%$ \\
\hline & Strategy & - & - \\
\hline & 8 & - & - \\
\hline & $\begin{array}{c}\text { Strategy } \\
9\end{array}$ & 2 & $1.1 \%$ \\
\hline & Strategy & 1 & $060 \%$ \\
\hline & 10 & 1 & $0.6 \%$ \\
\hline & Mixed & 11 & 620 \\
\hline & Strategy & 11 & $0.2 \%$ \\
\hline & I Speech & 177 & $100 \%$ \\
\hline
\end{tabular}

The data of table 4.1 above is the novel data "HELLA S. HAASSE'S " Key
Eye "which has 204 pages with 113 conversations has received 177 speeches with details, containing positive sentence of 100 speeches or 56.5 percent, and negative politeness of 77 speeches or 43.5 percent. From positive politeness, speech is grouped into 15 strategies of politeness. Furthermore, from negative politeness, the utterances are grouped into 10 strategies of politeness. Of the 25 politeness strategies, whether positive or negative politeness, there are some speeches that may include more than one positive politeness strategy or more than a negative politeness strategy, in the table called a mixed strategy.

Table 4.2

Number of Speech Containing Maxim According to Geoffrey Leech

\begin{tabular}{|c|c|c|c|}
\hline $\begin{array}{c}\mathbf{N} \\
\mathbf{0}\end{array}$ & Maxim & $\begin{array}{l}\text { Numbe } \\
\text { r of } \\
\text { speech } \\
\text { es }\end{array}$ & $\begin{array}{l}\text { Percenta } \\
\text { ge of } \\
\text { speech }\end{array}$ \\
\hline 1 & Wisdom & 18 & $16,1 \%$ \\
\hline 2 & Generosity & 7 & $6,3 \%$ \\
\hline 3 & Appreciati & 20 & $17,9 \%$ \\
\hline 4 & on & 2 & $1,8 \%$ \\
\hline 5 & Simplicity & 17 & $15,2 \%$ \\
\hline 6 & $\begin{array}{l}\text { Agreement } \\
\text { Sympathy }\end{array}$ & 48 & $42,9 \%$ \\
\hline \multicolumn{2}{|c|}{ Total speech } & 112 & $100 \%$ \\
\hline
\end{tabular}
In table 4.2 above, the maxim of language politeness according to Geoffrey

BAHTERA : Jurnal Pendidikan Bahasa dan Sastra, Volume Juli 2018 
found the analysis of the novel 'HELLA S.

HAASSE' Key Eye which has 204 pages, and 113 conversations, received 112 utterances containing maximal language pronunciation according to Geoffrey Leech with details, maxim of Wisdom as many as 18 utterances or 16.1 percent, maxim generosity of 7 speech or 6.3 percent, maxim Award of 20 speakers or 17.9 percent. Maxim Simplicity of 2 speech or 1.8 percent, maxim agreement as much as 17 speech or 15.2 percent, maxim sympathy as much as 48 speech or 42.9 percent. As described in the results of the study, the discussion of the findings of this study fits the focus and sub focus of the study. Discussion of research findings that fit the focus and sub focus of the study is an interpretation or verification of the findings by linking the concepts and theories contained in the literature review chapter. Discussion of research findings based on the focus of research that is, language politeness, with sub focus research that is, positive politeness and negative politeness Brown and Levinson, and maxim according to Geoffrey Leech.

\section{DISSCUSION}

Speech that contains politeness in the novel 'HELLA S. HAASSE' Key Eye is found to occur in various social spheres, starting from the scope of family, friendship, school, office, and so forth. Speeches found in accordance with the principles and concepts of civility according to Brown and Levinson, and maxim according to Geoffrey Leech. The Brown and Levinson Principles are so specific and universal that they can provide a basis for interaction and use of language. Likewise with the principles and concepts of the maxim according to Geoffrey Leech, giving a very specific and universal explanation of the use of language in social life.

1. Positive Politeness

Speeches containing positive politeness in the novel 'Key Eye works of HELLA S. HAASSE' can be found in the form of speech that concerns the likes, desires, and needs of the opponent. Exaggerate a sense of attraction, approval, and sympathy for the other person. Intensify attention to the opponent. Use a marker that shows the similarity of identity or group. Seek 
consent with the opponent. Avoid conflict with the opponent of speech. Shows things that are deemed to have similarities through basic talk (small talk) and presuppositions. Use a joke. Declare understanding of the opponent's desire to say. Provide offers and appointments. Showing optimism. Involve the opponents of speech and speakers in a particular activity. Give and ask for suggestions. And give sympathy to the opponent said.

Findings like the above very in accordance with the concept of positive politeness is, politeness to keep a positive face opponent said. Positive facial refers to the self-image of every rational person, who wants what he does, what he has admitted to others. Of the various speeches that included positive politeness, it turns out that efforts made by speakers to keep a positive face of the opponent said very diverse as positive politeness strategies according to Brown and Levinson.

2. Negative Perseverance

Speeches containing negative politeness in Key Eye novel by HELLA S. HAASSE are grouped in to 10 strategies of politeness. In addition, there are some speeches that contain more than one negative politeness strategy. Speech can be found in the form of command and request query such as in the form of questions or solicitation with apology or show the inability of speakers to minimize coercion, and so forth. From the results of data analysis in the form of speech, it was found that not all speeches use polite language.

3. Maxim according to Geoffrey Leech Speeches containing the maxims of language pronunciation according to Geoffrey Leech are divided into the maxims of wisdom, maxim of dignity, maxim of appreciation, maxim of simplicity, maxim of consensus, and maxim of sympathy.

\section{CONCLUSION}

The meaning of politeness is a speech accompanied by the actions spoken by the speaker without the potential to hurt the feelings of the opponent said or other people who became the topic of conversation to create comfort in speaking and maintaining social relationships that

BAHTERA : Jurnal Pendidikan Bahasa dan Sastra, Volume Juli 2018 
have been established. Politeness is divided into two namely positive politeness and negative politeness. Positive politeness is the politeness of speech spoken by speakers to appreciate and respect what is owned and done by the opponent said by raising the degree of the opponent said. Negative politeness is the utterance of speech spoken by speakers to keep the opponent said not annoyed and burdened because the actual speech in the form of orders or requests by softening the speech or humble themselves. In addition, the definition of the novel is obtained.

1. Positivity politeness in the speech of the novel character 'Key Eye by HELLA S. HAASSE'

Positive courtesy in the novel 'HELLA S. HAASSE' novel's novel, speeches that pay attention to the likes, desires, and needs of the opponent, exaggerate the sense of attraction, approval, and sympathy with the opposite; intensify attention to the opponent of speech; seek approval with the opponent of speech; avoid conflict with the opponent of speech; shows things that are considered to have similarities through small talk and presupposition; using a joke, declaring familiarity with his opponent's wishes; provide offers and appointments; show optimism; involve the spokesman and speaker in a particular activity, giving and asking for an excuse; will give sympathy to the opponent said.

2. Negative politeness in the speech of the novel character 'Key Eye by HELLA S. HAASSE

Negative politeness in the novel 'HELLA S. HAASSE' Key Eye novel's speech in the form of a speech that expresses indirectly according to convention, uses, minimizes coercion, questions; show a pessimistic attitude; pay homage, use apologies; not mentioning speakers and opponents of speech; nominate a statement; and states clearly that the opponent of speech has given good or not to the speaker.

3. Maxim according to Geoffrey Leech in the speech figure novel 'Key Eye works of HELLA S. HAASSE'

The analysis of the 204 pages 'HELLA S. HAASSE' novel of 'Key Eye', and 113 conversations, received 112 utterances containing speechdependent maxims according to Geoffrey Leech with details, a 
maximum of 18 speeches or 16.1 percent, maxim Generosity of 7 speeches or 6.3 percent, maxim Awards of 20 speakers or 17.9 percent. Maxim Simplicity of 2 speech or 1.8 percent, maxima agreement as much as 17 speech or 15.2 percent, maxim sympathy as much as 48 speech or 42.9 percent.

Thus, the principles of politeness according to Brown and Levinson, as well as the maxim of language pronunciation according to Geoffrey Leech, can explain universally language pragmatism in the pragmatic field. Language politeness in the pragmatic field can not only be learned from direct speech in social life, but can be learned through novels that are presented attractively with conflicts in the plot.

\section{ACKNOWLEDGEMENT}

From the results of the research and the theories on which it is based, it can be recommended that the novel can be described in terms of language, relationships, and age, such as in family, community, school and office environment. Language readers and learners can get a picture of the speeches that include language courtesy through conversations and conflicts that are presented with many variations. In addition, the element of humor is an added value that makes the reader and language learners will not feel saturated at the time of reading the novel but the humor presented is still adapted to the prevailing culture in society. From the novel advantages of "HELLA S. HAASSE's Key Eye" derived from this study, it is possible that other novels have these advantages, perhaps even more. Therefore, teachers or teachers can use novels as an alternative source of learning for students to be able to get a picture and understand about language politeness.

Then, to understand the politeness of language, the principles of politeness according to Brown and Levinron can be used to describe the specific and universal speech by examining deeper meanings and speeches according to the situation, context, or pragmatic review of the utterance, so that it can be the right choice for researchers from the next language field. For further research it is recommended that research be undertaken 
by delving deeper into the cultural side, comparing pragmatic pragmatism with linguistics, or the difference in politeness in foreign languages with politeness in the Indonesian language.

\section{REFERENCES}

Brown and Gilman, Analysis of the Use of Pronouns in Languages, (Jakarta: 1994) BUNGIN BURHAN, Qualitative Research

Data Analysis, (Jakarta: PT Raja GRAFINDO PERSADA, 2006)

Crystal, David, THE Cambridge Encyclopedia of Language, (Cambridge: CAMBRIDGE UNIVERSITY PRESS.LEVINSON, 1987)

Ministry of National Education, Big Indonesian Dictionary, (Jakarta: BALAI PUSTAKA, 2003)

EMZIR, Qualitative Research Methodology Data Analysis, (Jakarta: RAJAGRAFINDO PERSADA, 2010)

F. X. NADAR, Pragmatic and Pragmatic Research, (Yogyakarta: GRAHA ILMU, 2009)

Geoffrey Leech, Pragmatic Principles, (Jakarta: University of Indonesia Press, 1993)
HARIYONO, Indonesian Junior High

School Grade 9, (Bogor: BP, 2008)

HELLA S. HASSE, Key Eye, (Jakarta: METAFOR PUBLISHING, 2002)

I DEWA PUTU WIJANA, Pragmatic Basics, (Yogyakarta: ANDI Yogyakarta, 1996)

John R. Searle, Speech Act: An Essay in the Philosophy of Language, (Cambridge: Cambridge University Press, 1969)

K. M. JASZCOZOIT, Semantics and Pragmatics, (London: Pearson Education, 2002)

MALEONG, LEXY J., Qualitative Research Methodology, (Bandung: PT REMAJA ROSDAKARYA, 2010)

NAOMI GAVER, Discourse and Politeness: Ambivalent Face in Japanese, (British: CANTINUUM, 2008)

NURGIANTORO BURHAN, Theory of Fictional Assessment, (Yogyakarta: GADJAH MADA University Press, 2005)

NURGIANTORO BURHAN, Theory of Fictional Assessment, (Yogyakarta: GADJAH MADA University Press, copyright VI, 2007) 
BAHTERA: Jurnal Pendidikan Bahasa dan Sastra, Volume 17 Nomor 2 Juli 2018 http://journal.unj.ac.id/unj/index.php/bahtera/

Patrick Griffiths, An Introduction to English Semantics and Pragmatics, (Edinburgh: Edinburgh University Press, 2006)

RAHARDI KUNJANA, Pragmatic Imperative Indonesian Language, (Jakarta: ERLANGGA 2005)

RAHARDI KUNJANA, Pragmatic, (Jakarta, ERLAND, 2005)

Richard J. Watts. Politeness, (United Kingdom: Cambridge, 2003)

SAEKO FUKUSHIMA, Request and Culture: Politeness in British English and Japanese, (Germany: Peter Lang, 2003)

SETIYADI BAMBANG, Research Methods for Foreign Language Teaching: Quantitative and Qualitative Approach, (Yogyakarta: GRAHA ILMU, 2006)

Stephen C., Pragmatics, (Cambridge: Cambridge University Press, 1983)

Verhaar, J.W.M., Principles of General Linguistics, (Yogyakarta: Gajah Mada University Press, 1996) 